\title{
Fusarium Species Associated with Corm Rot of Taro in Bogor
}

\author{
WIDODO* AND SUPRAMANA \\ Depariment of Plant Prolection, Faculty of Agriculture, Institut Pertanian Bogor \\ Jalan Kamper, Kampux Darnaga, Bogor 16680, Indonesia
}

\begin{abstract}
In Bogor-West Java, corm rot disease of taro has devastated in many cropping areas and caused yield losses up to $70 \% \%$. During preliminary studies, Fusarium species were constantly recovered when diseased materials, rotten corms and discolored petioles were incubated. The objectives of this study was to identify the Fusarium species associated with the corm rot disease in Bogor and determine their pathogenicity and hosts range. Samples were collected from 40 diseased corm samples taken in 9 sub- districts of Bogor. Two species, viz, Fusarium solani and F, oxysporum were identified based on the morphological characteristics. Amorig 40 Fusarium isolates rocoverod in this study, $70 \%$ were $F$. solani and $30 \%$ were $F$. axysporum. F. solani could infect to all tested edible Araceae, while $F$ axysporum was only pathogenic to Colocasia esculenta. Both species of Fusarium did not cause any symptorns when inoculated on selected omamental Araceae and legume crops. These results gave the indication that $F$ solani was probably pathogenic only to edible Araceae, but further inoculation assay on living taro plants are necessary to carry out in order to clarify this result.
\end{abstract}

Key words: corm rot, Fusarium solani, F. oxysporum, taro.

Penyakit busuk umbi merupakan salah satu penyakit penting pada talas di wilayah Bogor dan dapat menimbulkan kehilangan hasil sampai 70\%. Dalam pengamatan awal, Fusarium secara konsisten selalu ditemukan jika bagian tanaman sakit diinkubasikan, baik umbi yang membusuk maupun jaringan pembuluh tangkai daun yang mengalami perubahan warna. Penelitian ini dilakukan untuk mengklarifikasi kemungkinan beberapa spesies Fusarium sebagai penyebab busuk umbi talas melalui uji patogenisitas dan kisaran inang. Hasil penelitian menunjukkan dua spesies Fusarium, yaitu $F$ solani dan $F$. axysporim telah didentifikasi berdasarkan ciri-ciri morfologi dari 40 contoh tanaman sakit yang diambil dari 9 kecamatan di wilayah Bogor. $F$ solani dan $F$ axysporum masing-masing mencakup $70 \%$ dan $30 \%$ dari 40 isolat Fusarium yang dikumpulkan. $F$, solani ditemukan di semua kecamatan yang diambil contoh tanaman sakitnya, sedangkan $F$. oxysporum hanya ditemukan di 7 kecamatan. $F$. solani dapat menyebabkan pembusukan pada semua famili Araceae yang dapat dikonsumsi, sedangkan $F$. oxysporum hanya menimbulkan pembusukan pada tanaman talas (Colocasia esculenta). Kedua spesies Fusarium tidak dapat menimbulkan gejala apa pun ketika diinokulasikan pada tanaman hias famili Araceae, kacang panjang, dan buncis. Penelitian ini menunjukkan kedua spesies Fusarium sebagai penyebab busuk umbi pada talas. F. solani dapat menjadi patogen busuk umbi pada semua tanaman famili Araceae yang dapat dikonsumsi, sementara itu $F$, oxysponim sebagai patogen spesifik pada tanaman talas dan diduga scbagai formae speciales tertentu.

Kata kunci: busuk umbi, Fusarium solani, F, oxysporum, talas.

Taro is one of the most popular secondary crops planted in several areas around Bogor, West Java. This crop, as a fresh corm or in its processed products, is also as a Bogor-special gift for many domestic tourists who visit this city. To increase income and welfare, Bogor farmers who generally possess limited land, tend to grow more crops per year by practicing various types of multiple cropping systems. Although taro is of significant cash value to farmers, most farmers cultivate this crop together with other crops species, because of its long growth period and their limited land allocation. However some farmers, especially in Southern Bogor do cultivate taro in monoculture. There are many cultivars grown in this area, but the two cultivars known by the local farmers as "Bentul" and "Hijau" are the most frequently planted.

There is an emerging corm rot disease that causes yield losses up to $70 \%$ observed in several fields in Bogor in 2000 (Burdani et al. 2001). However, based on the field survey of several areas, many farmers

*Corresponding author, Phone/Fax: +62-251-8423048. E-mail: widodo@ipb.ac.id mentioned that the disease have threatened their crops since 1998 and even as far back as 1995. The continuous mono cropping practiced by many farmers resulted in this disease building up in the field. In most cases, farmers did not detect the aboveground symptoms until 5 months after planting, or 2 to 3 months before harvest. When the first above ground symptom appeared, over a half of the corm is often already rotted and as a consequence unmarketable (Burdani et al. 2001). The disease caused uneven shoot emergence when attacked in early growing stage. In preliminary investigations, Fusarium spp. were recovered consistently from surface disinfected symptomatic plants incubated in a moist chamber (Widodo and Supramana, unpublished data).

There is no confirmed report a species of Fusarium causing taro corm rot in Indonesia. However, in many countries including New Hebrides, Hawaii, and Solomon Islands; $F$. solani and $F$. oxysporum have been reported as minor pathogen (Jackson and Gollifer 1975). In Japan, Komada (1998) reported F. solani as the causal agent of corm rot disease of sato imo. Nishimura and Kudo (1994) also reported that taro dry 
rot caused by Fusarium oxysporum has been causing serious losses in Miyakonojo-Miyazaki, Japan.

Since the accurate identification of the causal agent of plant diseases is the key information in the determination of control measures, the results of this study will be valuable for that purpose. The objectives of the study presented here was to determine what species of Fusarium were associated with diseased taro corm in some subdistricts in Bogor area and the pathogen host range. This information would be valuable and may provide some understanding for strategic management of the disease.

\section{MATERIALS AND METHODS}

Field Survey. Preliminary surveys were conducted to observed characteristic, above or below grown symptoms, and the most common cultivars planted by farmers in surveyed areas. Samples of diseased corms were surface disinfected with $70 \%$ alcohol, and incubated in moist chamber to induce the fungal sporulation. Nine subdistricts, representing the large taro-growing areas in Bogor were sampled (Table 1).

Isolation. Forty individual diseased plant samples were collected from eighteen villages of nine subdistricts in Bogor area. One or both of two cultivars, Bentul and/or Hijau, were sampled depending on the planted cultivars during the study.

Field Survey. Individual diseased corms were surfaced disinfected by wiping with $70 \%$ alcohol wetted cotton, sliced transversally into $5 \mathrm{~mm}$ thickness with sterilized knife, and then cut in small cubes $(5 \mathrm{~mm}$ x $5 \mathrm{~mm}$ x $5 \mathrm{~mm}$ ) between the rotten and healthy tissue. Five to ten pieces of the tissue were dipped in $10 \%$ household bleach ( $0.525 \%$ sodium hypochlorite) for $10 \mathrm{sec}$, rinsed in sterilized distilled water, and blotted dry on tissue paper. Pieces were placed onto potato dextrose agar (PDA) mixed with two drops of $20 \%$ lactic acid per petri dish and incubated at room temperature $\left( \pm 27^{\circ} \mathrm{C}\right)$ under near ultra violet $(366 \mathrm{~nm})$ with a $12 \mathrm{~h}$ photoperiod. After 5 days incubation, upon small pieces of colonised agar from actively growing margins where Fusarium grew from the tissue were sub-cultured onto PDA. Single spore cultures

Table 1 Number and places of diseased plant samples collected

\begin{tabular}{lc}
\hline Subdistrict & $\begin{array}{l}\text { Number of individual plant } \\
\text { samples }\end{array}$ \\
\hline Ciomas & 12 \\
Sukaraja & 4 \\
Bogor Timur & 2 \\
Kemang & 3 \\
Bogor Selatan & 4 \\
Cijeruk & 4 \\
Ciawi & 3 \\
Bogor Barat & 4 \\
Dramaga & 4 \\
\hline Total & 40 \\
\hline
\end{tabular}

were established onto water agar, sub-cultured again onto PDA, and 7 to 10 days later.

Identification based on conidial size, conidiogenesis, conidial form, chlamydospores formation were determined on cultures grown on carnation leaf agar (CLA) medium, and then identified according to the taxonomic system outlined by Leslie and Summerell (2006).

Inoculation on Sliced Taro Corm. The experiment was performed on two taro cultivars, cv. Bentul and cv. Hijau commonly planted in Bogor. The corms harvested from healthy individual plants of taro in commercial farmer field were surface disinfected with $70 \%$ alcohol, and sliced transversally into $1.5 \mathrm{~cm}$ thickness with sharp sterilized knife. Each Fusarium isolate tested were cultured on PDA for 7 days in room temperature under NUV with $12 \mathrm{~h}$ photoperiod were plugged with cork borer $(\varnothing 5 \mathrm{~mm})$ from actively growing colonies. Inoculation was performed by putting plugs of each isolate on the centre of 3 taro corm slices, in which the fungal colony faced the corm tissues. Taro corm slices inoculated with PDA plugs only were used as control. The treated taro corm slices were placed in plastic box moist chamber by placing cotton wetted with sterile water, covered with plastic wrap, and incubated in dark room. Daily observation up to about 5 days after inoculation was done to determine the presence of rotting symptom and incubation period.

Inoculation on the Whole Unsliced Taro Corms. Pathogenicity tests was also performed using the whole unsliced corms with the same inoculation method as mentioned previously, except for the observation period, which was conducted up to 2 weeks after inoculation.

Inoculation with Single and Combination of Isolates on Sliced Taro Corm. Taro slices cv. Bentul was prepared with the methods as mentioned in the previous experiment and inoculated with conidial suspension, either in singly or combination of species recovered. Conidial suspensions of $F$. solani and $F$. oxysporum were prepared by adding sterile distilled water to 7 to 10 day's old cultures rubbing the culture surface with a sterile glass spatula, shaking thoroughly, and filtering through four sterilized layers of cheesecloth. The conidial suspensions were adjusted into $1.25 \times 10^{6} \mathrm{~mL}^{-1}$ by means of bright line haemocytometer. The conidial suspension $(0.05 \mathrm{~mL})$ of fungus cultures were inoculated singly and in combination onto taro corm slices using micropipette, and placed in plastic box moist chamber, covered with plastic wrap and incubated in the dark at room temperature $\left( \pm 27{ }^{\circ} \mathrm{C}\right)$. Five days after inoculation rotting diameter on 6 corm slices of each treatments was observed. 
Inoculation on Vegetative Propagation of Taro. Two cultivars of taro (cv. Hijau and Bentul) were used in the experiment. The planting medium containing soil and goat manure $(4: 1 \mathrm{v} / \mathrm{v})$ was twice heat sterilized in two consecutive days, each for $30 \mathrm{~min}$ at $120^{\circ} \mathrm{C}$ using autoclave. Conidial suspensions of Fusarium species was prepared using the same method as mentioned previously Ten healthy plants were selected for freedom from disease, washed the attached soils with tap water, dipped in diluted commercial clorox solution $(0.525 \%$ sodium hypochlorite) for $60 \mathrm{sec}$, and then rinsed with sterile water. Each set of test plants were dipped in conidial suspension of each Fusarium isolates for $24 \mathrm{~h}$, grown in pots containing about $2 \mathrm{~L}$ prepared medium, and fertilized with N:P:K (15:15:15) 3 weeks after planting. Control plants were inoculated with sterile water only. Development of disease symptoms was studied during 3 months.

Host Range Tests. This experiment was performed on other edible and ornamental Araceae and commonly legume crops planted by taro farmers, as follows: giant taro (Alocasia macrorhiza), blue taro (Xanthosoma violaceum), Chinese evergreen (Aglaonema commutatum), dumb cane (Dieffenbachia seguine), angel wings (Caladium bicolor), nephthytis (Syngonium podophyllum), long yard bean (Vigna ungiculata), and French bean (Phaseolus vulgaris).

Inoculation on Sliced Edible Araceae Corm. Sliced edible Araceae corm and inoculation procedure was performed using the same methods as mentioned in previous experiment.

Inoculation on Ornamental Araceae. Some species of ornamental Araceae (A. commutatum, D. seguine, C. bicolor, and $S$. podophyllum) were used in the experiment. Inoculation was performed on vegetative propagation using dipping method with conidial suspensions as described previously.

Inoculation on Legume Crops. Long yard bean and French bean commercial seeds was first surface disinfected by dipping in the diluted commercially clorox for $60 \mathrm{sec}$, rinsed in sterile water for 2 times, and then germinated in plastic box contained heat sterilized sand. Germinated seeds were soaked in conidial suspension $\left(1.25 \times 10^{6} \mathrm{~mL}^{-1}\right)$ for $24 \mathrm{~h}$ and planted in plastic pots contained heat sterilized planting medium as mentioned in previous experiment. Development of disease development was observed once a week for 2 months.

\section{RESULTS}

Field Observation. Foliar symptoms include leaf curling or crinkling, leaf browning from the edge, chlorosis, shrivelling and withering of petiole, was the distinct easily detected in the fields. During the field observation, we found 2 type of above ground symptoms, that were plant suddenly died without changing of leaf colours (Fig 1a), and preceded with leaf yellowing (Fig 1b). Advanced disease development caused wilting, stunting of individual plants which eventually die. When the diseased plant was cut transversally, an internal symptom includes vascular discoloration and corm rotting appeared (Fig 1c and 1d). In severely infected areas, many cluster-stunted plants showed the empty hollow patches (Fig 1e). Diseased plant was easily pulled out when corm have already completely rotted. The similar symptoms as observed in this study have also been described on taro in Japan (Nishimura and Kudo 1993) and on konnyaku (Amorphophallus konjach) (Shibata and Aoki 1994).

Pathogen Isolation, Identification, and Pathogenicity Test on Taro. From several observations in preliminary studies with different individual diseased plant samples incubated in moist chamber, Fusarium was consistently isolated. Two species of Fusarium were found among 40 cultures recovered from taro corm showed wilting and/or chlorotic symptoms in above ground from 9 different sub districts in Bogor, West Java (Table 2). Two species of Fusarium identified as F. solani and F. oxysporum were recovered from 40 samples associated with taro corm rot disease in 9 different subdistricts in Bogor-West Java. F. solani was observed as the predominant species recovered from $70 \%$ of the total diseased plant samples. Both species of Fusarium species were recovered from individual plant samples showing sudden death symptoms above ground, meanwhile only $F$. oxysporum was detected from diseased plants with leaf yellowing symptom. The 2 species of Fusarium recovered were identified as $F$. solani and $F$. oxysporum based on their specific characters, especially microconidiophore and the formation of microconidium in false heads with long or short monophialides, respectively (Fig 2a-b and 2e-f). These 2 species, $F$. solani and $F$. oxysporum comprised $70 \%$ and $30 \%$ of the total samples, respectively (Table 2 ).

Colonies of $F$. solani identified in this study was fast growing on PDA after 2-3 days, white or cream with spares mycelium. Numerous micro- and macroconidia were formed on CLA medium. Microconidia produced on elongate monophialide conidiogenous cells (Fig 2b); ellipsoid or reniform with 0 or 1-septate (Fig 2c), $8-16 \times 4-8 \mu \mathrm{m}$, and formed in false heads (Fig 2a). Macroconidia wide, straight, stout with blunt apical cell, basal cell poorly developed 3 -septate, 27-39 $\mu \mathrm{m} \times$ x 4-7 $\mu \mathrm{m}$ (Fig 2d). Chlamydospores formed abundantly, either terminally or intercalary, and rapidly within 2 weeks on CLA, 3.9-7.8 $\mu \mathrm{m}$ in diameter (Fig 2e). 

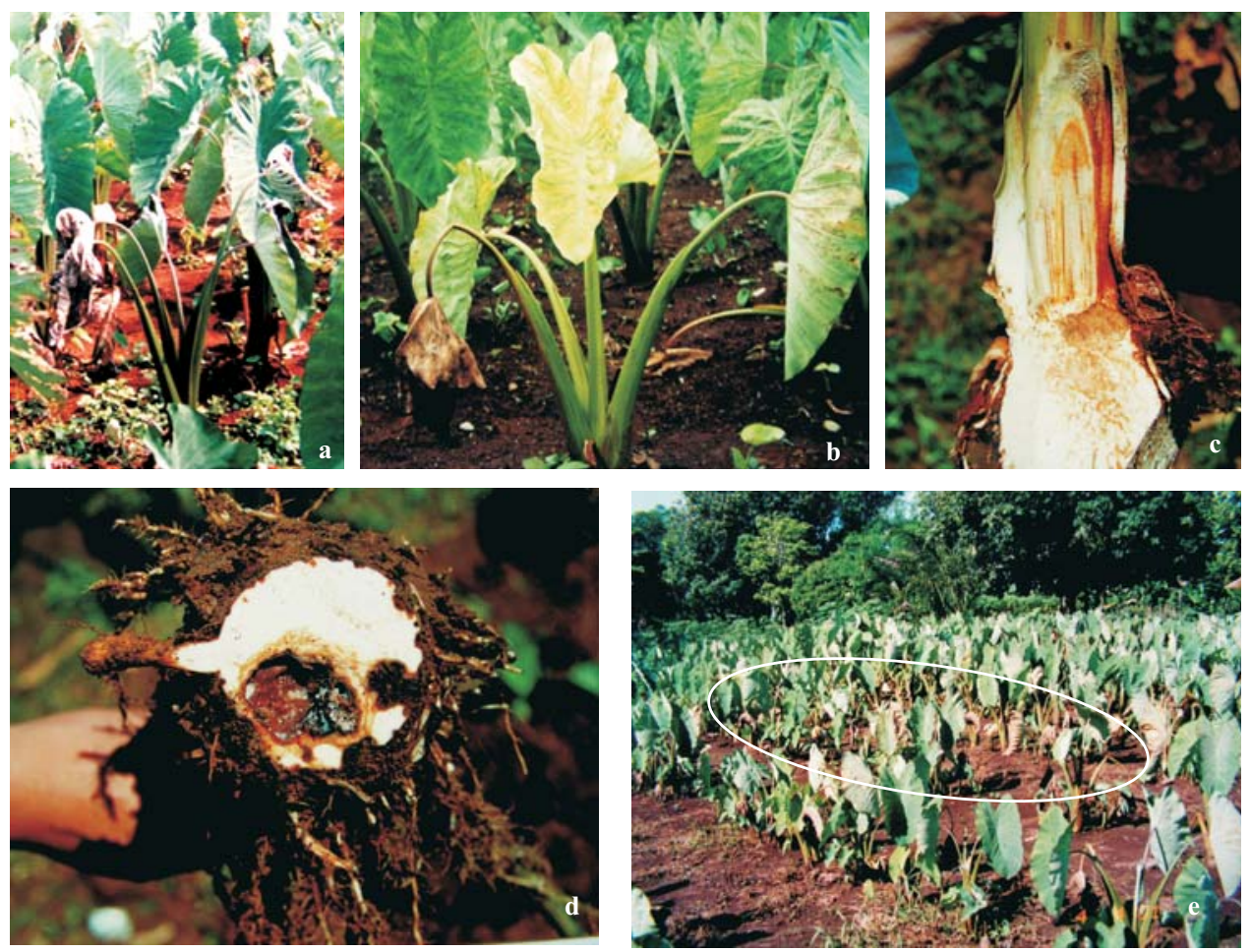

Fig 1 Variation of field symptoms of taro corm rot. a, Wilting and leaf curling symptom; b, leaf chlorosis; c, corm and leaf petiole discoloration; d, corm rotting and hollowing; e, cluster symptom in the field (circled).
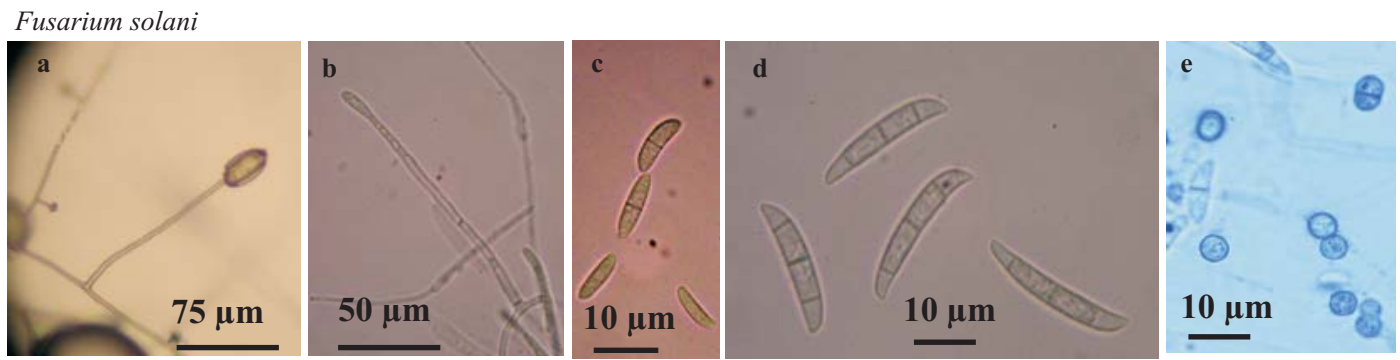

Fusarium oxysporum
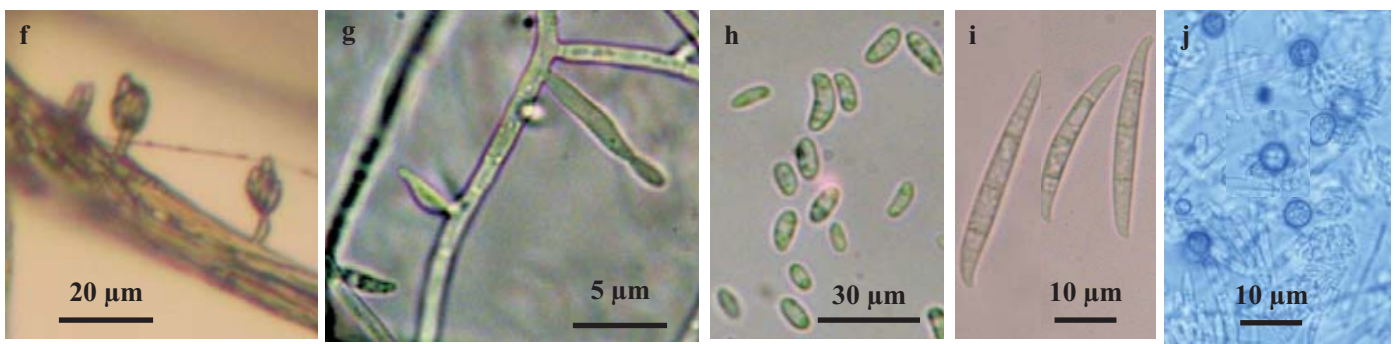

Fig 2 Microscopically characters of Fusarium solani and F. oxysporum associated with taro corm rot based on microconidium on conidiophore, microconidium and macroconidium size on CLA medium. a, Falsehead of $F$. solani with long microconidiophore; b, Microconidiophore; c, Microconidia; d, Macroconidia; e, Chlamydospores; f. Falsehead of F. oxysporum with short microconidiophore; g, Microconidiophore; h, Microconidia; i, Macroconidia; j. Chlammydospores

Pure cultures of the other suspect pathogen identified as F. oxysporum was fast growing, mycelia floccose with range in colour from pale to dark violet on PDA. Micro- and macroconidia abundantly produced on CLA medium. Microconidia abundant, formed in falsehead on short lateral monophialides (Fig $2 \mathrm{f}$ and $2 \mathrm{~g}$ ), ellipsoidal to cylindrical, straight or kidney shape (Fig 2h), 8-15 $\mu \mathrm{m} \times$ x 4-8 $\mu \mathrm{m}$. Macroconidia straight to slightly curved, relatively slender than F. solani, apical cell tapered or curved with a slight hook, 27-39 $\mu \mathrm{m} \times$ 4-5 $\mu \mathrm{m}$ (Fig 2i). Chlamydospores abundantly produced on CLA medium within 2 weeks after inoculation, formed either terminally or intercalary in hyphae, with diameter in range of 3.9-7.8 $\mu \mathrm{m}$ (Fig 2j).

Both Fusarium species was recovered from the individual plant samples showing sudden death symptom on above ground, while isolation from the diseased plant samples with leaf yellowing only F. oxysporum was observed. Both Fusarium species 
Table 2 Distribution and composition of Fusarium species associated with corm rot of taro in Bogor, West Java - Indonesia

\begin{tabular}{|c|c|c|c|}
\hline \multirow[t]{2}{*}{ Subdistrict } & \multirow{2}{*}{$\begin{array}{l}\text { Number of } \\
\text { samples }\end{array}$} & \multicolumn{2}{|c|}{$\begin{array}{l}\text { Number of Fusarium species } \\
\text { recovered }\end{array}$} \\
\hline & & F. solani & F. oxysporum \\
\hline Ciomas & 12 & 7 & 5 \\
\hline Sukaraja & 4 & 3 & 1 \\
\hline Bogor Timur & 2 & 2 & 0 \\
\hline Kemang & 3 & 3 & 0 \\
\hline Bogor Selatan & 4 & 3 & 1 \\
\hline Cijeruk & 4 & 3 & 1 \\
\hline Ciawi & 3 & 2 & 1 \\
\hline Bogor Barat & 4 & 2 & 2 \\
\hline Darmaga & 4 & 3 & 1 \\
\hline Total isolates & & 28 & 12 \\
\hline Proportion (\%) & & 70 & 30 \\
\hline
\end{tabular}

Table 3 Pathogenicity of single and mixed inoculation with $F$. solani and $F$. oxysporum on cv. Bentul

\begin{tabular}{lc}
\hline \multicolumn{1}{c}{ Fusarium species } & Corm rotting diameter $(\mathrm{cm})^{*}$ \\
\hline F. solani & $4.02 \pm 0.79 \mathrm{a}^{* *}$ \\
F. oxysporum & $3.80 \pm 1.02 \mathrm{a}$ \\
F. oxysporum + F. solani & $4.56 \pm 1.07 \mathrm{a}$ \\
\hline
\end{tabular}

$* 5$ days after inoculation, $* *$ not significantly different $(P=0.05)$

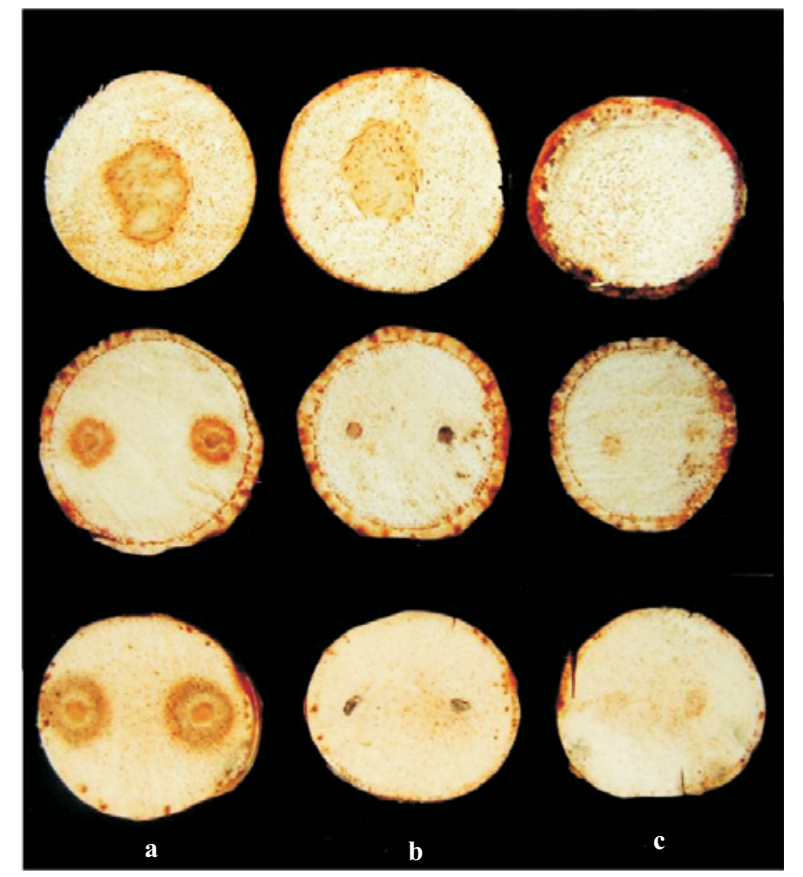

Fig 3 Inoculation test of $F$. solani and $F$. oxysporum on taro (top), giant taro (middle), and blue taro (bottom) using sliced corm. a, F.solani; b, F. oxysporum; c, non-inoculated

were also pathogenic and caused rotting on either $\mathrm{cv}$. Bentul or cv. Hijau. Mixed inoculation with both species of Fusarium although tended to show larger rotting on sliced taro corm than single treatment, but was not significantly different (Table 3).

In the inoculation to whole unsliced taro corm assay, corm rotting were formed after 2 weeks incubation period. Corm surface showed water soaking symptom, and when peeled rotting have spread around the inoculation site in $3 \mathrm{~mm}$ depth. Unfortunately, the pathogenicity test by inoculation on vegetative propagation of taro did not show any specific above ground symptoms in 3 months after inoculation, however, corms rotting have slightly occurred and the 2 Fusarium species were reisolated.

Host Range Tests. Rotting on sliced giant taro (A. macrorhiza) and blue taro (X. violaceum) only occurred when inoculated only by F. solani (Fig 3). Three months after single inoculation with $F$. oxysporum or $F$. solani on taro vegetative propagation, all treated plants did not show any above ground symptoms, but slight rotted on corm was formed. Above ground symptomatic also were not formed when both Fusarium species inoculated onto long yard bean, bean, and some ornamental Araceae: chinese evergreen, dumb cane, angel wings, and Syngobium.

\section{DISCUSSION}

Although a number of Fusarium species, including $F$. solani and $F$. oxysporum, are commonly known as saprophytes (Summerell et al. 2003) from diseased roots and stem bases, our study showed that both Fusarium species were capable of causing rotting symptoms on sliced taro corm. Unfortunately, inoculation assay on vegetative propagation of taro did not show any above ground symptoms after 3 months incubation period. We predicted that, it might need more than 3 months of incubation for the Fusarium species to initiate the above ground symptoms. In our interview with the farmers during the field survey, the above symptoms could be detected at least 5 months after planting when they use the healthy propagations. Generally, $F$. oxysporum is well known as a causal agent of wilt diseases of over 100 cultivated plant species, including tomato, potato, sugarcane, bean, cowpea, date and oil palm, as well as cooking and dessert bananas, but rotting symptom caused by this species was also reported on various plant species, such as rose (Barguil et al. 2009), saffron (Di Primo and Cappelli 2000), and amaranths (Chen and Swart 2001) as also observed in our study. These 2 species were also revealed as causal agents on other Araceae plant, calla lily, with dwarfism, wilting, damping off, and tuber dry rotting symptoms (Ciampi et al. 2009). Meanwhile Fusarium tuber rot incited by $F$. solani was reported as the most important disease that affects ornamental caladium (Knauss 1975). In other root crop such as cassava, numerous and diverse species of Fusarium were associated with rotted cassava roots, with the 2 largest of the AFLP groups corresponds to $F$. oxysporum and F. solani (Bandyopadhyay et al. 2006). The occurrences of the same disease of taro caused by F. solani as in our study have also been reported in Hawaii (Raabe et al. 1981). In Solomon Islands corm 
rot of taro have also been reported with various causal agents, including Pythium myriotylum, P. Splendens, and F. oxysporum (Jackson and Gollifer 1975), while other researchers identified more specifically, that the causal agents of corm rot on other Araceae crop (Amorphophallus) was $F$. solani f. sp. radicicola (Nieda 1985) and F. oxysporum f. sp. colocasiae (Nishimura and Kudo 1994; Shibata and Aoki 1994). The 2 species of Fusarium, F. solani and F. oxysporum, were also recovered from storage cocoyam (Colocasia spp.) showing spoilage symptoms in Nigeria and have been confirmed as causal agents of the disease in pathogenicity tests (Ugwuanyi and Obeta 1996), while in Cameroon F. solani was one of the fungal species associated with the destructive root rot disease of cocoyam (Pacumbaba et al. 1992). F. solani was also one of the fungal consistently reisolated from the cocoyam rotting tissue arising from inoculation among 2 others fungi, Botryodiplodia theobromae and Sclerotium rolfsii (Maduewesi and Onyike 1981). These 2 Fusarium species were also confirmed have an association with and caused rotting symptom on white yam (Dioscorea rotundata) during storage (Ezeibekwe and Ibe 2010). Other researcher determined that $F$. proliferatumwas reported as one of the causal agents of storage rot of taro in Guam (Wall and Cruz 1991). Although the colony between $F$. proliferatum and $F$. oxysporum often appear similar on PDA, but these species easily distinguished by the presence of microconidia in chains for $F$. proliferatum and the presence of chlamydospores and microconidia in false heads for F. oxysporum as indicated in our study. The consistent recovery 2 Fusarium species during our preliminary observation by incubating of several diseased corms in moist chamber and pathogenicity tests in this study, we think that those 2 species are the causal agents of taro corm rot disease in Bogor.

Based on host range tests, only $F$. solani was pathogenic to all tested edible Araceae, while $F$. oxysporum was more specific to C. esculenta. Neither $F$. solani nor F. oxysporum isolated from diseased taro caused any symptoms on the ornamental Araceae and legume crops tested. It is possible that the $F$. oxysporum associated with taro corm rot might be a specific pathogen to $C$. esculenta as previously described by Nishimura and Kudo (1994) as F. oxysporum f. sp. colocasiae. Cross inoculation tests of 17 formae speciales of $F$. oxysporum to taro have been conducted by other researcher (Nishimura and Kudo 1994), and they proposed for the taro isolates as $F$. oxysporum Schl. f. sp. colocasiae Nishimura et Kudo. Other researcher reported that $F$. solani was determined as causal agent of cutting rot disease of $D$. maculate and did not show any symptom when inoculated to other members of the family Araceae ornamental plants (Chase and El-Gholl 1982). From this report, it is also possible that the F. solani recovered from our research might be a specific pathogen to members of the family Araceae edible crops as reported by Nieda (1985) on Amorphophallus rivieri . Further inoculation assay on living taro plants are necessary to carry out to clarify this hypothesis.

\section{ACKNOWLEDGMENTS}

We thank the Quality for Undergraduate Education (QUE) Project, Department of Plant Protection, Institut Pertanian Bogor for research grant support in conducting the studies described in this manuscript.

\section{REFERENCES}

Bandyopadhyay R, Mwangi M, Aigbe SO, Leslie JF. 2006. Fusarium species from the cassava root rot complex in West Africa. Phytopathology 96(6):673-676. doi:10.1094/PHYTO-96-0673.

Barguil BM, Viana FMP, Anjos RM, Cardoso JE. 2009. First report of dry rot caused Fusarium oxysporum on rose (Rosa spp.) in Brazil. Plant Dis 93(7):766. doi: 10.1094/PDIS-93-7-0766A.

Burdani DH, Supramana, Widodo. 2001. Studi lini dasar penyakit busuk umbi pada talas (Colocasia esculenta ( L.) Schott) di Bogor [Base line study on the corm rot disease of taro (Colocasia esculenta ( L.) Schott) in Bogor]. Bul Hama Peny 13 (1):6-14.

Chase AR, El-Gholl NE. 1982. Stem rot, cutting rot, and leaf spot of Dieffenbachia maculate 'Perfection' incited by Fusarium solani. Plant Dis 66 (7):595-598. doi:10.1094/PD-66-595.

Chen WQ, Swart WJ. 2001. Genetic variation among Fusarium oxysporum isolates associated with root rot of Amaranthus hybridus in South Africa. Plant Dis 85(11):1076-1080. doi:10.1094/PDIS.2001.85.10. 1076.

Ciampi LP, Nissen MJ, Venegas GE, Fuentes PR, Costa ML, Schöbitz TR, Alvarez DE, Alvarado AP. 2009. Identification of two species of Fusarium Link that cause wilting of colored callas (Zantedeschia aethiopica (L.) Spreng) cultivated under greenhouse conditions in Chile. Chil J Agric Res 69(4):516-525. doi:10.4067/S071858392009000400006.

Di Primo P, Cappelli C. 2000. Preliminary characterization of Fusarium oxysporum $\mathrm{f}$. sp. gladioli causing Fusarium corm rot of saffron in Italy. Plant Dis 84(7):806. doi:10.1094/PDIS-91-9-1203B.

Ezeibekwe IO, Ibe AE. 2010. Fungal organisms associated with yam (Dioscorea rotundata Poir) rot at Owerri, Imo State of Nigeria. J Mol Gen 2(1):1-5. doi: 10.3923/jmolegene.2010.1.5.

Jackson GVH, Gollifer DE. 1975. Disease and pest problems of taro (Colocasia esculenta L. Scott) in the British Solomon Islands. PANS 21:45-53.

Knauss JF. 1975. Description and control of Fusarium tuber rot of caladium. Plant Dis Rep 59(12):975-979.

Leslie JF, Summerell BA. 2006. The Fusarium laboratory manual. $1^{\text {st }}$ ed. Iowa:Blackwell Publ,

Maduewesi JNC, Onyike RCI. 1981. Fungal rotting of cocoyams in storage in Nigeria. In: Terry ER, Oduro KA, Caveness F, editors. Tropical Root Crops: Research Strategies for the 1980s, Proceeding of the First Triennial Root Crops Symposium of the International Society for Tropical Root Crops-Africa Branch; 1980 Sep 8-12, Ibadan, Nigeria, Ottawa: International Development Research Centre, p 235-238.

Nieda H. 1985. Ecology and control of konnyaku (Amorphophallus rivieri) dry-rot (Fusarium solani f.sp. radicicola). Gunma J Agric Res 3(2):89-146. (in Japanese).

Nishimura N, Kudo K. 1993. Disease development and chlamydospore formation in taro (Colocasia) dry rot caused by Fusarium 
oxysporum. Bull Kyushu Natl Agric Exp Stn 28(1):45-52. (in Japanese).

Nishimura N, Kudo K. 1994. Fusarium oxysporum f. sp. colocasiae n. f. sp. causing dry rot of taro (Colocasia esculenta). Ann Phytopathol Soc Jpn 60(4):448-453.

Ogaraku AO, Osman HO. 2008. Storage rot of some yams (Dioscorea spp.) in Keffi and Evirons, Nasarawa State, Nigeria. Prod. Agric Technol 4(2):22-27

Pacumbaba RP, Wutoh JG, Eyango SA, Tambong JT, Nyochembeng LM. 1992. Isolation and pathogenicity of rhizosphere fungi of cocoyam in relation to cocoyam root rot disease. J Phytopathol 135(4):265-273. doi:10.1111/j.1439-0434.1992.tb04312.x.

Raabe, RD, Conners, IL, Martinez, AP. 1981. Checklist of Plant Diseases in Hawaii. College of Tropical Agriculture and Human Resources,
University of Hawaii . Information Text Series No. 22. Honolulu: Trop Agric Human Resources.

Shibata S, Aoki T. 1994. Dry rot of konnyaku (Amorphophallus konjac Koch) caused by Fusarium oxysporum. Ann Phytopathol Soc Jpn 60(6):748. (in Japanese).

Summerell BA, Salleh B, Leslie JF. 2003. A utilization approach to Fusarium identification. Plant Dis 87(2):117-127. doi:10.1094/PDIS. 2003.87.2.129.

Ugwuanyi JO, Obeta JAN. 1996. Fungi associated with storage rot of cocoyams (Colocasia sp.) in Nsukka, Nigeria. Mycopathologia 134(1):21-25. doi: 10.1007/BF00437048.

Wall GC, Cruz JF. 1991 Lasiodiplodia theobromae and Fusarium proliferatum causing storage rots of taro in Guam. Plant Dis 75(12):1286. doi:10.1094/PD-75-1286D.. 